principle of U.S. constitutional law, the president's "power is at its lowest ebb" when "tak[ing] measures incompatible with the ... will of Congress." 47 Should Trump seek to effectuate the U.S. withdrawal without fulfilling all the conditions set forth in the joint resolution, he would be acting in violation of a congressional mandate. ${ }^{48}$

\title{
INTERNATIONAL ECONOMIC LAW
}

\section{United States-Mexico-Canada Agreement Enters into Force}

doi:10.1017/ajil.2020.74

On November 30, 2018, Canada, Mexico, and the United States signed an agreement renegotiating the North American Free Trade Agreement (NAFTA). By the spring of 2020, all three countries had approved this agreement-known in the United States as the United States-Mexico-Canada Agreement (USMCA) ${ }^{1}$ - through their respective domestic ratification processes. The USMCA entered into force on July 1, 2020, amid extended U.S.-Mexico and U.S.-Canada border restrictions due to the COVID-19 pandemic. On August 6, 2020, President Trump imposed tariffs on Canadian aluminum-tariffs that his administration had previously put in place in 2018 but had removed in 2019 in order to smooth the USMCA's path to ratification.

The negotiation of the USMCA took place over the first two years of the Trump administration. The agreement, signed on November 30, 2018, changed some of NAFTA's key provisions, including eliminating investor-state dispute settlement between the United States and Canada and modifying the rules of origin for automobiles. ${ }^{2}$ The USMCA also added new provisions "address[ing] intellectual property rights, rights for indigenous persons, rules for trade negotiations with non-market countries, and the agreement's termination."3

\footnotetext{
"withdrawals that fail ... to identify [a] justification under international law ... assert an authority that the Senate likely did not contemplate when approving the treaty").

${ }^{47}$ Youngstown Sheet \& Tube Co. v. Sawyer, 343 U.S. 579, 637 (1952) (Jackson, J., concurring).

48 See Murrill \& HART, supra note 42, at 3 (observing that "the President arguably may lack the authority to withdraw from the WHO if he does not adhere to these conditions because Congress enacted them using its constitutional Spending Clause power"); $c f$. Restatement (FourTh) of Foreign Relations Law, supra note 46, $\$ 313$ reporters' note 6 (noting that if the power to withdraw from Article II treaties is not exclusive to the president, Congress may have the power to limit withdrawals through statutes).

1 The agreement is referred to as the United States-Mexico-Canada Agreement (USMCA), the Canada-United States-Mexico Agreement (CUSMA), or Tratado entre México, Estados Unidos y Canadá (T-MEC), depending on the country referring to the agreement. See Office of the U.S. Trade Rep. Press Release, United States-MexicoCanada Trade Fact Sheet: Modernizing NAFTA into a 21st Century Trade Agreement (Oct. 2018), at https://ustr. gov/trade-agreements/free-trade-agreements/united-states-mexico-canada-agreement/fact-sheets/modernizing [https://perma.cc/F67G-XN5L]; Gov't of Canada Press Release, A New Canada-United States-Mexico Agreement (Aug. 20, 2020), at https://www.international.gc.ca/trade-commerce/trade-agreements-accordscommerciaux/agr-acc/cusma-aceum/index.aspx?lang=eng [https://perma.cc/77Z8-L96P]; Gov't of Mexico Press Release, Textos Finales del Tratado Entre México, Estados Unidos y Canadá (T-MEC), at https://www. gob. $\mathrm{mx} / \mathrm{t}$-mec/acciones-y-programas/textos-finales-del-tratado-entre-mexico-estados-unidos-y-canada- $\mathrm{t}$-mec202730 ? state $=$ published.

${ }^{2}$ Jean Galbraith, Contemporary Practice of the United States, 113 AJIL 150, 150 (2019).

${ }^{3} I d$. at 155 . For further discussion of the USMCA's content, see id. at 150-59.
} 
The USMCA did not resolve the steel and aluminum tariffs that the Trump administration had imposed on Canada and Mexico earlier in 2018 (or the retaliatory tariffs imposed by Canada and Mexico). On May 17, 2019, the United States agreed with these two countries to lift these tariffs, though providing for possible reimposition if steel or aluminum imports "surge meaningfully beyond historic volumes of trade over a period of time." ${ }^{4}$ These developments reportedly removed a significant political obstacle to the ratification of the USMCA. ${ }^{5}$

On June 19, 2019, Mexico became the first country to receive legislative approval for the USMCA. ${ }^{6}$ The path in the United States was not as easy, and the U.S. House of Representatives successfully insisted on modifications to certain USMCA provisions, including "strengthen[ing] compliance mechanisms for the labor and environmental provisions [and] reduc[ing] intellectual property protections for certain kinds of pharmaceuticals." On December 12, Mexico's Senate once more approved the USMCA, as renegotiated. ${ }^{8}$ On December 19, 2019, and January 16, 2020, respectively, the U.S. House of Representatives and Senate approved the revised USMCA through the passage of the United States-MexicoCanada Agreement Implementation Act, which Trump signed into law on January 29.9 Canada's legislature gave its approval on March 13, 2020, just before taking an extended pause in light of the COVID-19 pandemic. ${ }^{10}$

In April of 2020, the three countries formally notified each other that they had "completed the internal procedures required for the entry into force" of the USMCA and its associated

\footnotetext{
${ }^{4}$ Office of the U.S. Trade Rep. Press Release, United States Announces Deal with Canada and Mexico to Lift Retaliatory Tariffs (May 17, 2019), at https://ustr.gov/about-us/policy-offices/press-office/press-releases/2019/ may/united-states-announces-deal-canada-and [https:/perma.cc/W9GC-BHS4]; Office of the U.S. Trade Rep. Press Release, Joint Statement by the United States and Canada on Section 232 Duties on Steel and Aluminum, available at https://ustr.gov/sites/default/files/Joint_Statement_by_the_United_States_and_Canada.pdf [https:// perma.cc/237R-6HHL] (further providing that any retaliatory tariffs would occur "only in the affected sector (i.e., aluminum and aluminum-containing products or steel)"); Office of the U.S. Trade Rep. Press Release, Joint Statement by the United States and Mexico on Section 232 Duties on Steel and Aluminum, available at https://ustr.gov/sites/default/files/Joint_Statement_by_the_United_States_and_Mexico.pdf [https://perma.cc/ 482V-3RY3] (including the same provision regarding retaliatory tariffs).

${ }^{5}$ David J. Lynch, Emily Rauhala \& Damian Paletta, Trump Did Something Unusual on the Trade Front: He Removed a Tariff, WASH. POST (May 17, 2019), at https://www.washingtonpost.com/business/economy/ trump-delays-auto-tariff-threat-for-up-to-180-days/2019/05/17/95432e8e-78a7-11e9-b7ae-390de4259661_ story.html.

${ }^{6}$ Mary Beth Sheridan, Mexico Becomes First Country to Ratify New North American Trade Deal, WASH. POST (June 19, 2019), at https://www.washingtonpost.com/world/the_americas/mexico-becomes-first-country-toratify-usmca-north-american-trade-deal/2019/06/19/500dd8c0-92b3-11e9-956a-88c291ab5c38_story.html (noting the Mexican Senate's overwhelmingly supportive vote of 114 to 4).

${ }^{7}$ Jean Galbraith, Contemporary Practice of the United States, 114 AJIL 137, 141 (2020) (citing Speaker of the House Press Release, Transcript of Speaker Pelosi Press Conference Announcing New USMCA Agreement (Dec. 10, 2019), at https://www.speaker.gov/newsroom/121019-2). Canada and Mexico signed a revised version of the USMCA that incorporated these changes. Id.

${ }^{8}$ Anthony Esposito \& Peter Cooney, Mexican Senate Approves Changes to USMCA Regional Trade Deal, REUTERS (Dec. 12, 2019), at https://www.reuters.com/article/usa-trade-usmca/mexican-senate-approves-changes-tousmca-regional-trade-deal-idUSL1N28N00V.

9165 Cong. Rec. H12284-85 (daily ed. Dec. 19, 2019) (recording a vote of 385-41); 166 Cong. Rec. S266 (daily ed. Jan. 16, 2020) (recording a vote of 89-10); Donald J. Trump, Remarks on Signing the United StatesMexico-Canada Agreement Implementation Act, 2020 Daily Comp. Pres. Doc. No. 45 (Jan. 29).

${ }^{10}$ David Ljunggren, Canadian Parliament Rushes Through Ratification of USMCA Trade Pact, ReUTERS (Mar. 13, 2020), at https://www.reuters.com/article/us-usa-trade-usmca-canada/canadian-parliament-rushes-throughratification-of-usmca-trade-pact-idUSKBN2102I5.
} 
protocol. ${ }^{11}$ Pursuant to this protocol, the USMCA entered into force on July 1, 2020, on the "first day of the third month following the last notification." 12 This entry into force had the effect of "supersed[ing] the NAFTA, without prejudice to those provisions set forth in the USMCA that refer to provisions of the NAFTA," and of terminating the 1993 North American Agreement on Labor Cooperation. ${ }^{13}$

The USMCA's entry into force occurred amid the COVID-19 pandemic. Travel across both the U.S.-Mexico and the U.S.-Canada border has been limited since March 21, 2020, although these limits on "non-essential" travel are not aimed at critical goods or supply chains. ${ }^{14}$ It remains to be seen whether or how the entry into force of the USMCA will affect the economic situation of the three countries amid the pandemic. ${ }^{15}$ On July 8, 2020, Trump and Mexican President Andrés Manuel López Obrador released a joint statement highlighting the USMCA's role as an "ideal instrument to provide economic certainty and increased confidence to our countries, which will be critical to the recovery that has begun in both of our nations." 16

${ }^{11}$ Protocol Replacing the North American Free Trade Agreement with the Agreement Between the United States of America, the United Mexican States, and Canada, available at https://ustr.gov/sites/default/files/files/ agreements/FTA/USMCA/Text/USMCA_Protocol.pdf [https://perma.cc/TU6W-PWXM] [hereinafter Protocol]; Janyce McGregor, Canada Notifies U.S. and Mexico It Has Ratified Revised NAFTA, CBC News (Apr. 3, 2020), at https://www.cbc.ca/news/politics/nafta-cusma-canada-ratified-1.5520337 (reporting Canada to be the first country to give the notification); Office of U.S. Trade Rep. Press Release, USMCA to Enter into Force July 1 After United States Takes Final Procedural Steps for Implementation (Apr. 24, 2020), at https:// ustr.gov/about-us/policy-offices/press-office/press-releases/2020/april/usmca-enter-force-july-1-after-unitedstates-takes-final-procedural-steps-implementation (describing the United States as the third country to provide its notification).

${ }^{12}$ Protocol, supra note 11

${ }^{13} I d$.

${ }^{14}$ U.S. Dep't of Homeland Security Press Release, Fact Sheet: DHS Measures on the Border to Limit the Further Spread of Coronavirus (Aug. 14, 2020), at https://www.dhs.gov/news/2020/08/14/fact-sheet-dhs-measures-border-limit-further-spread-coronavirus [https://perma.cc/8FV4-REA7] (noting that these restrictions were initially set for thirty days but have since been continuously extended through September 31); U.S. Customs and Border Prot. Press Release, Temporary Restriction of Travelers Crossing US-Canada and Mexico Land Borders for Non-essential Purposes (Aug. 18, 2020), at https://help.cbp.gov/s/article/Article-1596?language=en_US (noting that "[s] upply chains, including trucking, will not be impacted"). Citing the pandemic, the United States has placed major new restrictions on asylum seekers crossing the border. See Jean Galbraith, Contemporary Practice of the United States, 114 AJIL 504, 510-11 (2020).

${ }^{15}$ See David A. Wemer, Start of USMCA Brings Hope Amid COVID-19 Economic Crisis, AtLantic Council (July 1, 2020), at https://www.atlanticcouncil.org/blogs/new-atlanticist/start-of-usmca-brings-hope-amid-covid-19economic-crisis (providing commentary on the USMCA's impact on the American economy during the pandemic); Meena Venkataramanan \& Julián Aguilar, Trump Called the USMCA the Best Trade Deal Ever. Analysts Say It's Not Likely to Help Texas During The Pandemic, Tex. Trib. (Aug. 12, 2020), at https://www.texastribune.org/2020/08/12/usmca-trade-agreement-coronavirus-texas-mexico ("But several months into a COVID-19 pandemic that continues to ravage the global economy, analysts say there isn't anything in the USMCA that's going to make an immediate difference and help offset the massive economic losses caused by the pandemic."). In addition to the ongoing pandemic, some issues that remain in the implementation of the USMCA include "hundreds of legal challenges to Mexico's new labor law championed by President Andrés Manuel López Obrador to ensure that workers can freely organize and unions are granted full collective bargaining rights." David Lawder, Dave Graham \& David Ljunggren, New North American Trade Deal Launches Under Cloud of Disputes, Coronavirus, Reuters (June 30, 2020), at https://www.reuters.com/article/us-usa-trade-usmca/newnorth-american-trade-deal-launches-under-cloud-of-disputes-coronavirus-idUSKBN2424E2. If the new labor laws are struck down, Mexico might not be able to implement labor-related provisions in the USMCA, prompting U.S. Representative Richard Neal, chairman of the House Ways and Means Committee, to accuse Mexico of "falling short of its commitments." Id.

${ }^{16}$ Joint Declaration by President Trump and President Andrés Manuel López Obrador of Mexico, 2020 DAILY Comp. Pres. Doc. No. 502 (July 8). 
On August 6, Trump reimposed a 10 percent tariff on certain aluminum products imported from Canada. ${ }^{17}$ Trump stated that the 2019 understanding reached with Canada lifting the prior tariffs had sought to "avoid import surges" but that, in the year immediately following this agreement, imports on these aluminum products "increased 87 percent compared to the prior twelve-month period and exceeded the volume of any full calendar year in the previous decade." 18 Canada's Deputy Prime Minister Chrystia Freeland responded by describing these tariffs as "unwarranted and unacceptable," noting that "[i]n the time of a global pandemic and an economic crisis, the last thing Canadian and American workers need is new tariffs." 19 She stated that "with the new NAFTA having come into force on July 1st, now is the time to advance North American economic competitiveness-not hinder it," and promised that Canada would "swiftly impose dollar-for-dollar countermeasures." 20

INTERNATIONAL CRIMINAL LAW

\section{President Trump Authorizes Economic Sanctions and Visa Restrictions Aimed at International Criminal Court}

doi:10.1017/ajil.2020.77

In the spring of 2020, the Appeals Chamber of the International Criminal Court (ICC) authorized the ICC's prosecutor to investigate alleged international crimes committed in Afghanistan. The Trump administration strongly condemned this decision. In an escalation of retaliatory measures against the ICC, President Trump signed an executive order authorizing economic sanctions against foreign persons involved in the investigation and visa restrictions against those persons and their immediate family members. The ICC described these actions as a threat to the rule of law.

On April 12, 2019, a Pre-Trial Chamber of the ICC declined to authorize the prosecutor to conduct an investigation into alleged international crimes committed in Afghanistan, reasoning that such an investigation would not advance the interests of justice. ${ }^{1}$ On March 5 ,

${ }^{17}$ Donald J. Trump, Proclamation 10060_-Adjusting Imports of Aluminum into the United States, 2020 Daily Comp. Pres. Doc. No. 578 (Aug. 6) [hereinafter Proclamation on Aluminum Tariffs] (providing for this tariff, effective August 16, on non-alloyed unwrought aluminum articles, which "accounted for 59 percent of total aluminum imports from Canada during June 2019 through May 2020").

${ }^{18}$ Id., paras. 3, 6; but see Amanda Coletta \& Jeanne Whalen, Canada Condemns "Entirely Unacceptable" U.S. Tariffs, Pledges to Retaliate with Levies on \$2.7 Billion of Goods, WASH. POST (Aug. 7, 2020), at https://www.washingtonpost.com/world/the_americas/canada-us-trade-trump-aluminum-tariffs/2020/08/07/793f30ba-d8b011 ea-a788-2ce86ce81129_story.html (noting that the U.S. Aluminum Association described these numbers as "cherry-picked" as "any increase in imports of non-alloyed aluminum in the first half of 2020 have been offset by a decline in imports of alloyed aluminum, and . . overall, imports of primary aluminum from Canada are 'near traditional levels"”).

${ }^{19}$ Office of the Deputy Prime Minister of Canada Press Release, Statement by the Deputy Prime Minister on US Tariffs on Imports of Canadian Aluminum (Aug. 6, 2020), at https://deputypm.canada.ca/en/news/statements/2020/08/06/statement-deputy-prime-minister-us-tariffs-imports-canadian-aluminum.

${ }^{20}$ Id.; see also Coletta \& Whalen, supra note 18 (describing the tariffs that Canada announced it would impose in response).

${ }^{1}$ See Situation in the Islamic Republic of Afghanistan, ICC-02/17-138, Judgment on the Appeal Against the Decision on the Authorisation of an Investigation into the Situation in the Islamic Republic of Afghanistan, para. 5 